\title{
Trovafloxacin Is Active against Toxoplasma gondii
}

\author{
ANIS A. KHAN, ${ }^{1}$ TERI SLIFER, ${ }^{1}$ FAUSTO G. ARAUJO ${ }^{1}$ AND JACK S. REMINGTON ${ }^{1,2 *}$ \\ Department of Immunology and Infectious Diseases, Research Institute, Palo Alto Medical Foundation, Palo Alto, \\ California 94301, ${ }^{1}$ and Division of Infectious Disease and Geographic Medicine, Department of Medicine, \\ Stanford University School of Medicine, Stanford, California $94305^{2}$
}

Received 1 April 1996/Returned for modification 23 May 1996/Accepted 7 June 1996

\begin{abstract}
Drugs currently used for treatment of toxoplasmosis in pregnant women, congenital infections, immunocompromised patients, and patients with the ocular disease are not always effective or may be dangerous to use; therefore, there is a need for more-effective and less-toxic drugs. Recently, we examined a group of fluoroquinolones for in vitro and in vivo activities against Toxoplasma gondii. Among those examined in vitro (ciprofloxacin, fleroxacin, ofloxacin, temafloxacin, tosufloxacin, and trovafloxacin), only trovafloxacin significantly inhibited intracellular replication of $T$. gondii without significant toxicity for host cells. In a murine model of acute toxoplasmosis, 100 or $200 \mathrm{mg}$ of trovafloxacin per $\mathrm{kg}$ of body weight per day for 10 days protected $100 \%$ of infected mice against death. A dose of $50 \mathrm{mg} / \mathrm{kg} / \mathrm{day}$ protected $90 \%$ of the mice, and a dose of $25 \mathrm{mg} / \mathrm{kg} /$ day effected prolongation of time to death. The other fluoroquinolones did not have such in vivo activities. These results indicate that trovafloxacin may be useful for treatment of toxoplasmosis in humans.
\end{abstract}

The current therapy of choice for all forms of human toxoplasmosis is the synergistic combination of pyrimethamine and sulfadiazine $(9,13,14,36)$. However, use of this combination in immunocompromised patients with AIDS is frequently associated with untoward side effects $(7,8,28,32)$ that can result in discontinuation of the therapy $(18,37)$. In addition, it has limited usefulness and efficacy in women who acquire the infection during pregnancy, in patients with ocular toxoplasmosis, and in congenitally infected infants and children. Therefore, there is a need for therapeutic agents that have potent activity against Toxoplasma gondii and less toxicity than the pyrimethamine-sulfadiazine combination.

During the past several years, we have studied a number of the fluoroquinolones to determine their activity against $T$. gondii in our murine models of toxoplasmosis. None of them had activity that was comparable to those of drugs already in use, until recently when we studied trovafloxacin, a new synthetic fluoronaphthyridone with broad-spectrum antibiotic activity $(1,19,20,33,34)$. This quinolone has rapid oral absorption (maximum concentration in serum at $1 \mathrm{~h}$ ), an oral bioavailability of 60 to $85 \%$, and a long half-life of elimination in healthy male volunteers (31). Here, we report results of our studies on the activity of fluoroquinolones against $T$. gondii.

\section{MATERIALS AND METHODS}

T. gondii. Tachyzoites of the RH strain of $T$. gondii were obtained and used as previously described $(2,10)$.

Mice. Outbred, female Swiss Webster mice (Simonsen Laboratories, Gilroy, Calif.), weighing approximately $20 \mathrm{~g}$ at the beginning of each experiment, were used. Mice were given water and food ad libitum.

Cells. L929 cells (ATCC CCL1) were used for in vitro experiments. Cells were grown in modified Eagle's medium (Gibco BRL, Grand Island, N.Y.) containing $100 \mathrm{U}$ of penicillin, $1 \mu \mathrm{g}$ of streptomycin per ml, and $10 \%$ heat-inactivated, $T$. gondii antibody-negative donor horse serum (PAA Laboratories, Newport Beach, Calif.)

Drugs. The following quinolones were studied: ciprofloxacin (Miles Inc., West Haven, Ct.), fleroxacin (lot CH903035; Hoffmann-La Roche, Nutley, N.J.),

\footnotetext{
* Corresponding author. Mailing address: Department of Immunology and Infectious Diseases, Research Institute, Palo Alto Medical Foundation, 860 Bryant St., Palo Alto, CA 94301. Phone: (415) 853 -6061. Fax: (415) 329-9853.
}

ofloxacin (RWJ Pharmaceutical Research Institute, Spring House, Pa.), temafloxacin and tosufloxacin (Abbott Laboratories, Abbott Park, Ill.), and trovafloxacin (Pfizer Inc., Groton, Ct.).

HPLC analysis. High-performance liquid chromatography (HPLC) assays were performed to measure trovafloxacin concentration in the drug dilutions used for the in vitro studies, with or without dimethyl sulfoxide. These assays were performed by Robert J. Polzer (Drug Metabolism Department, Pfizer Inc.) The range of trovafloxacin concentrations for the calibration assay was 0.1 to 20 $\mu \mathrm{g} / \mathrm{ml}$. Samples with anticipated concentrations above the upper limit of the standard calibration curve were diluted with HPLC-grade water prior to analysis. Quality control samples, including dilution quality controls, were all within $7 \%$ of their normal concentrations.

In vitro studies. Ciprofloxacin, fleroxacin, ofloxacin, temafloxacin, and tosufloxacin were tested at concentrations from 0.625 to $10 \mu \mathrm{g} / \mathrm{ml}$. Trovafloxacin was tested at concentrations from 0.25 to $20 \mu \mathrm{g} / \mathrm{ml}$. The same concentrations were used to determine toxicity of the drug for L929 cells. Each drug was dissolved in a small volume of dimethyl sulfoxide and brought to the required volume with modified Eagle's medium to prepare stock solutions for the in vitro assays. All dilutions were made in modified Eagle's medium. The final dimethyl sulfoxide concentration was less than $1 \%$. Since trovafloxacin is light sensitive, all solutions were made and stored in the dark. In vitro activity was defined as the capacity of the drug to inhibit intracellular replication of $T$. gondii and was determined by a modification of the previously described $\left[{ }^{3} \mathrm{H}\right]$ uracil incorporation technique (2). Briefly, L929 cells were plated at $10^{4}$ cells per well in 96-well flat-bottom tissue culture microtiter plates (Costar Corp., Cambridge, Mass.) and incubated at $37^{\circ} \mathrm{C}$ in a $5 \% \mathrm{CO}_{2}$ incubator. After confluence, monolayers were infected with tachyzoites at a ratio of 3 tachyzoites per cell (approximately $6 \times 10^{4}$ tachyzoites per well). Two hours following infection, the monolayers were washed to remove free parasites and various concentrations of the test drugs were added. Triplicate wells were used for each drug concentration. Addition of the drugs to the wells marked the starting time point. Four hours prior to harvesting of the cells, $\left[{ }^{3} \mathrm{H}\right]$ uracil $(1 \mu \mathrm{Ci}$ per well) was added to each well, and its incorporation was determined at 24,48 , and $72 \mathrm{~h}$ following addition of the test drug. Cells were collected with a cell harvester, and radioactivity was counted with a scintillation counter. Infected monolayers treated with medium that contained the respective drug diluent alone served as controls. Results are reported as inhibition of replication of tachyzoites in the treated monolayers compared with replication in the untreated control monolayer. Quantification was achieved by calculating the percentage of $\left[{ }^{3} \mathrm{H}\right]$ uracil incorporation by replicating tachyzoites in treated cultures compared with incorporation in untreated controls.

Toxicity of the drugs for the L929 cells was determined by the 3-(4,5-dimethylthiazol-2-yl)-2,5-diphenyl-tetrazolium bromide (MTT) cell proliferation assay using a Cell Titer 96 Kit (Promega Corp., Madison, Wis.). Briefly, cells were plated in triplicate wells at $10^{3}$ cells per well. Following a 4-h incubation at $37^{\circ} \mathrm{C}$ in a $5 \% \mathrm{CO}_{2}$, incubator test drugs were added. Four hours before each time point at 24,48 , or $72 \mathrm{~h}, 14 \mu \mathrm{l}$ of the dye indicator solution was added. Following an additional $4 \mathrm{~h}$ of incubation, $100 \mu \mathrm{l}$ of the solubilization-stop solution was added to each well. One hour later, the plates were read for $A_{570}$ in an automatic enzyme-linked immunosorbent assay plate reader. The results are reported as 


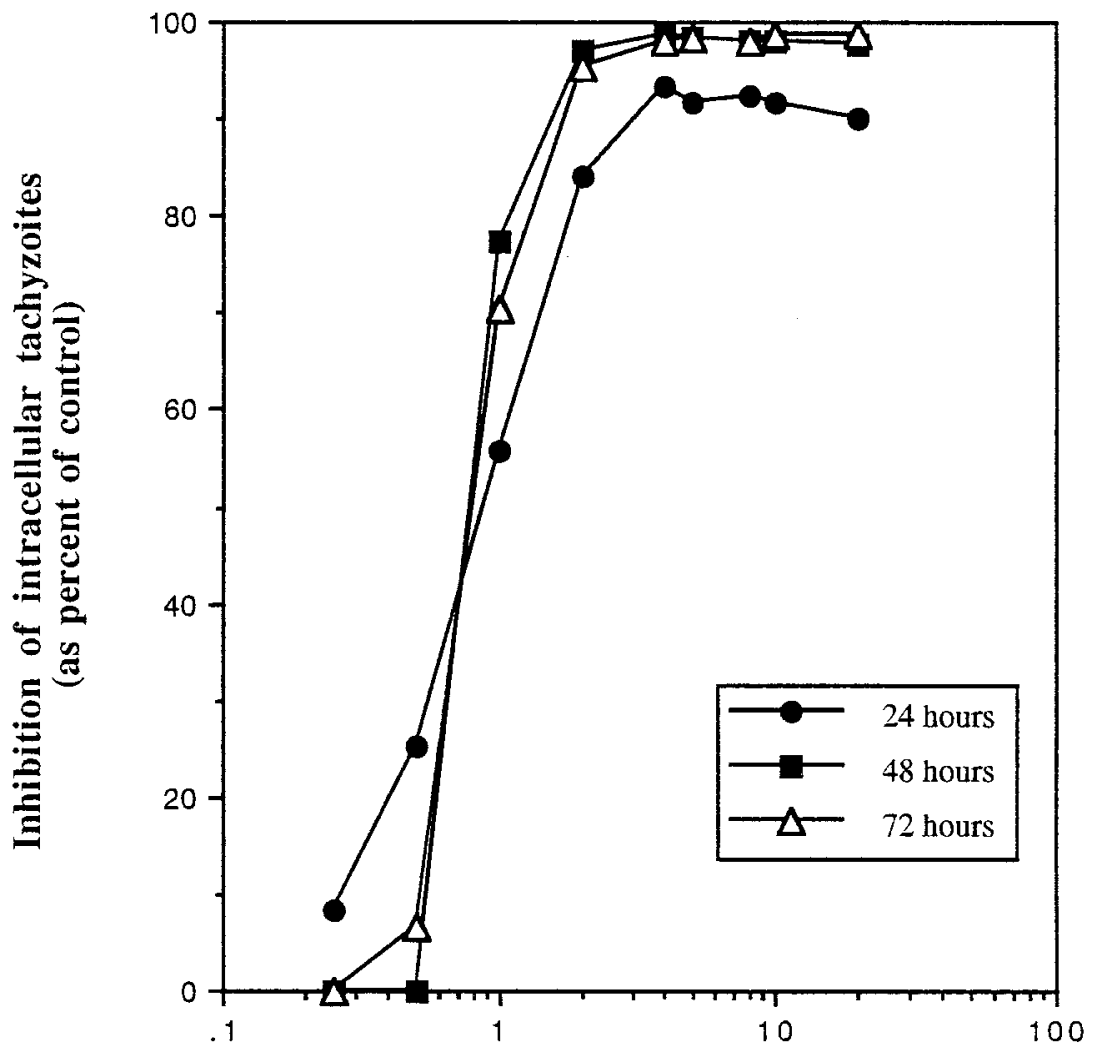

Dose, $\mu \mathbf{g} / \mathbf{m l}$

FIG. 1. Effect of trovafloxacin on intracellular tachyzoites in vitro. Trovafloxacin was used at 0.25 to $20 \mu \mathrm{g} / \mathrm{ml}$. Parasite growth was measured by [ $\left.{ }^{3} \mathrm{H}\right]$ uracil incorporation into intracellularly replicating tachyzoites.

the optical density at $570 \mathrm{~nm}$ of cultures exposed to the drug or exposed to the respective diluent only.

In vivo studies. For the in vivo experiments, solutions of the quinolones were made according to the manufacturer's directions: ciprofloxacin, temafloxacin, and trovafloxacin were dissolved in double-distilled water; ofloxacin and tosufloxacin were dissolved in a small volume of dimethyl sulfoxide and then diluted with double-distilled water to obtain the desired concentrations; fleroxacin was dissolved in a small volume of methanol, and the desired concentrations were obtained by adding polyethylene glycol. The following doses were used: ciprofloxacin, temafloxacin, and tosufloxacin at 25,50 , and $100 \mathrm{mg} / \mathrm{kg}$ of body weight per day; fleroxacin at $10,50,100$, and $200 \mathrm{mg} / \mathrm{kg}$ /day; ofloxacin at 50,100 , and 200 $\mathrm{mg} / \mathrm{kg} /$ day; and trovafloxacin at $25,50,100$, and $200 \mathrm{mg} / \mathrm{kg} /$ day.

Mice were infected with $2.5 \times 10^{3}$ tachyzoites intraperitoneally. Treatment was initiated $24 \mathrm{~h}$ later by gavage as a single daily oral dose and continued for 10 days. Mice were observed for 30 days from the day of infection for mortality and time to death. At the end of the 30-day period, brains of surviving mice were examined for the presence of $T$. gondii cysts as previously described (3). If cysts were not observed, portions of brain, liver, and spleen from treated mice were pooled and homogenized in sterile phosphate-buffered saline and portions of the suspensions were inoculated intraperitoneally into three normal mice (4). These subinoculated mice were observed for mortality for 30 days. Statistical analysis of the data was performed using survival tools for StatView, version 4.02 (Abacus Concepts, Berkeley, Calif.).

\section{RESULTS}

In vitro studies. Ciprofloxacin, fleroxacin, ofloxacin, temafloxacin, and tosufloxacin at concentrations from 0.625 to 10 $\mu \mathrm{g} / \mathrm{ml}$ either did not have demonstrable in vitro activity against $T$. gondii or were too toxic to the monolayers to have useful therapeutic indices (data not shown). Results with trovafloxacin in vitro revealed a dose-dependent inhibition of $T$. gondii
(Fig. 1). Results of three separate experiments revealed that the inhibitory concentration for $50 \%$ of the population following 24 to $72 \mathrm{~h}$ of exposure to the drug ranged from 0.77 to 0.98 $\mu \mathrm{g} / \mathrm{ml}$. Figure 2 illustrates the effects of various concentrations of trovafloxacin on the growth of L929 fibroblasts. Growth inhibition of the treated fibroblasts compared with that of the untreated controls was $<20 \%$ at a drug concentration of 2 $\mu \mathrm{g} / \mathrm{ml}$ at exposure times of 24 to $72 \mathrm{~h}$. However, at the same concentration, inhibition of $T$. gondii ranged from 87 to $99 \%$.

HPLC analysis was used to determine the concentration of trovafloxacin in the dilutions used in the experiments described above. The actual concentrations of trovafloxacin were similar to the predicted concentrations.

In vivo studies. Treatment with fleroxacin, ofloxacin, temafloxacin, and tosufloxacin did not result in any protective effect against death due to $T$. gondii infection (data not shown). Treated mice all died at essentially the same time as controls. Treatment with ciprofloxacin at $100 \mathrm{mg} / \mathrm{kg} / \mathrm{day}$ resulted in slight prolongation of time to death.

In contrast, all infected mice treated with 100 and $200 \mathrm{mg}$ of trovafloxacin per $\mathrm{kg}$ per day survived whereas control mice all died by day 10 (Fig. 3). Ninety percent of mice treated with 50 $\mathrm{mg} / \mathrm{kg} /$ day survived. The Kaplan-Meier product limited-survival analysis revealed a statistically significant difference in survival of the treated mice $(P<0.01, \log$ rank test). Treatment with $25 \mathrm{mg} / \mathrm{kg} /$ day resulted in prolongation of time to death which did not quite reach statistical significance $(P=$ 


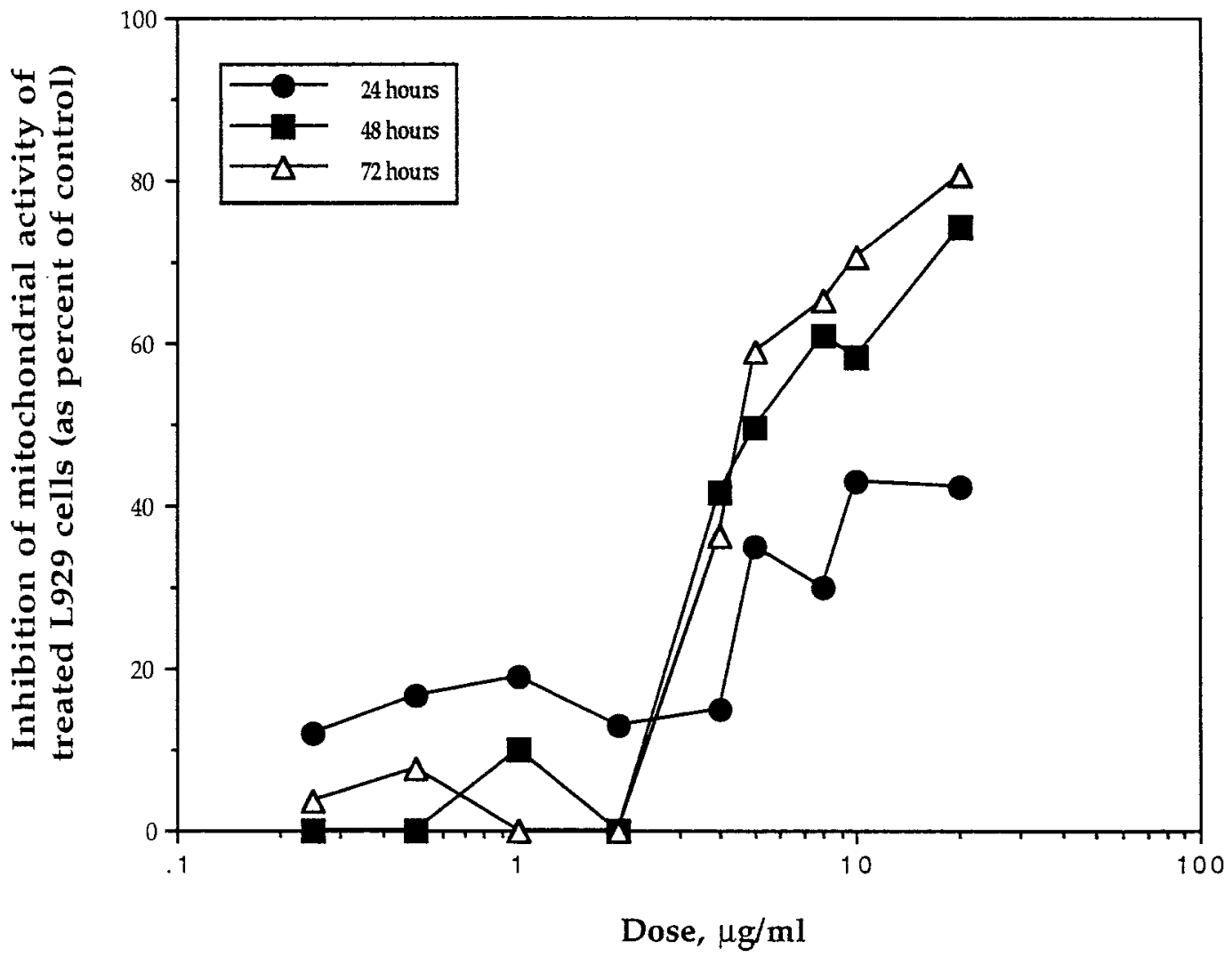

FIG. 2. Effect of trovafloxacin on L929 cells in vitro. Trovafloxacin was used at 0.25 to $20 \mu \mathrm{g} / \mathrm{ml}$. Growth of fibroblasts was measured by the MTT cell proliferation assay. (See Materials and Methods.)

0.06). Cysts were not observed in the brains of surviving mice, and $100 \%$ of the mice subinoculated orally with $0.2 \mathrm{ml}$ of the homogenates of brain, liver, and spleen obtained from surviving mice treated earlier with 50, 100, and $200 \mathrm{mg}$ of trovafloxacin per $\mathrm{kg}$ per day survived.

\section{DISCUSSION}

The results described above reveal that trovafloxacin is active against $T$. gondii both in vitro and in vivo. The other fluoroquinolones examined for in vitro activity, ciprofloxacin, fleroxacin, ofloxacin, temafloxacin, and tosufloxacin, did not have activity or were too toxic to the host cells to allow evaluation of drug effect on $T$. gondii per se. Trovafloxacin did not have a significant toxic effect on fibroblasts at concentrations that were highly active against $T$. gondii. Whereas trovafloxacin was also remarkably active against $T$. gondii in a murine model of acute toxoplasmosis, other fluoroquinolones tested did not have such activity. Survival of mice subinoculated with tissues of mice treated with trovafloxacin revealed that a 10-day schedule of treatment with trovafloxacin at $\geq 50 \mathrm{mg} / \mathrm{kg} /$ day eliminated viable parasites from tissues, since even a few viable parasites of the RH strain will kill a mouse.

Fluoroquinolone antibiotics possess potent activity against many bacterial pathogens and are extensively used in the treatment of a wide range of gram-positive and gram-negative bacterial infections (16). The mode of action of most quinolones against bacteria is directed to the DNA gyrase, a prokaryotic type II topoisomerase $(17,38)$, by converting it into a cellular poison by enhancing enzyme-mediated DNA breakage $(17,23$,
29). The mechanism of action of trovafloxacin against $T$. gondii, however, is unknown.

Recent studies of the pharmacokinetics of trovafloxacin in healthy adult volunteers have revealed that it is well tolerated at $\leq 300 \mathrm{mg}$ administered orally $(22,31,35)$ and is rapidly absorbed and that peak concentrations are achieved within 0.75 to $1 \mathrm{~h}$ of administration $(31,35)$. The half-life of elimination in humans was 10 to $12 \mathrm{~h}(6,22,31)$, and age or gender did not appear to have an effect on its pharmacokinetics (30). Mean concentrations in serum ranged from $0.3 \pm 0.0$ to $10.1 \pm$ $0.5 \mu \mathrm{g} / \mathrm{ml}$ at dosages from 30 to $1,000 \mathrm{mg}$ when administered as a single oral dose (31). In two studies, a single oral dose of 200 $\mathrm{mg}$ of trovafloxacin achieved concentrations in serum of 2.9 and $2.2 \mu \mathrm{g} / \mathrm{ml}(21,35)$. These concentrations of the drug were active against $T$. gondii in our in vitro studies.

Pneumonia caused by $T$. gondii has been found to cause significant morbidity and mortality in patients with AIDS (11, $26,27,37)$. Thus, it is of interest to note that significant concentrations of trovafloxacin were achieved in bronchoalveolar cells following a single oral dose of $200 \mathrm{mg}$ to lung transplant recipients (21). Trovafloxacin may therefore prove to be useful for treatment of toxoplasmic pneumonia.

T. gondii causes debilitating disease in congenitally infected infants and children. It was recently reported that in children from whom cerebrospinal fluid samples were obtained for various reasons (unspecified), with a median age of 4.7 years, trovafloxacin had rapid and inflammation-independent penetration into cerebrospinal fluid and significant concentrations in serum following a 1-h infusion of CP-116,517, an intravenous prodrug of trovafloxacin, at $180 \mathrm{mg} / \mathrm{m}^{2}(5)$. Because sol- 


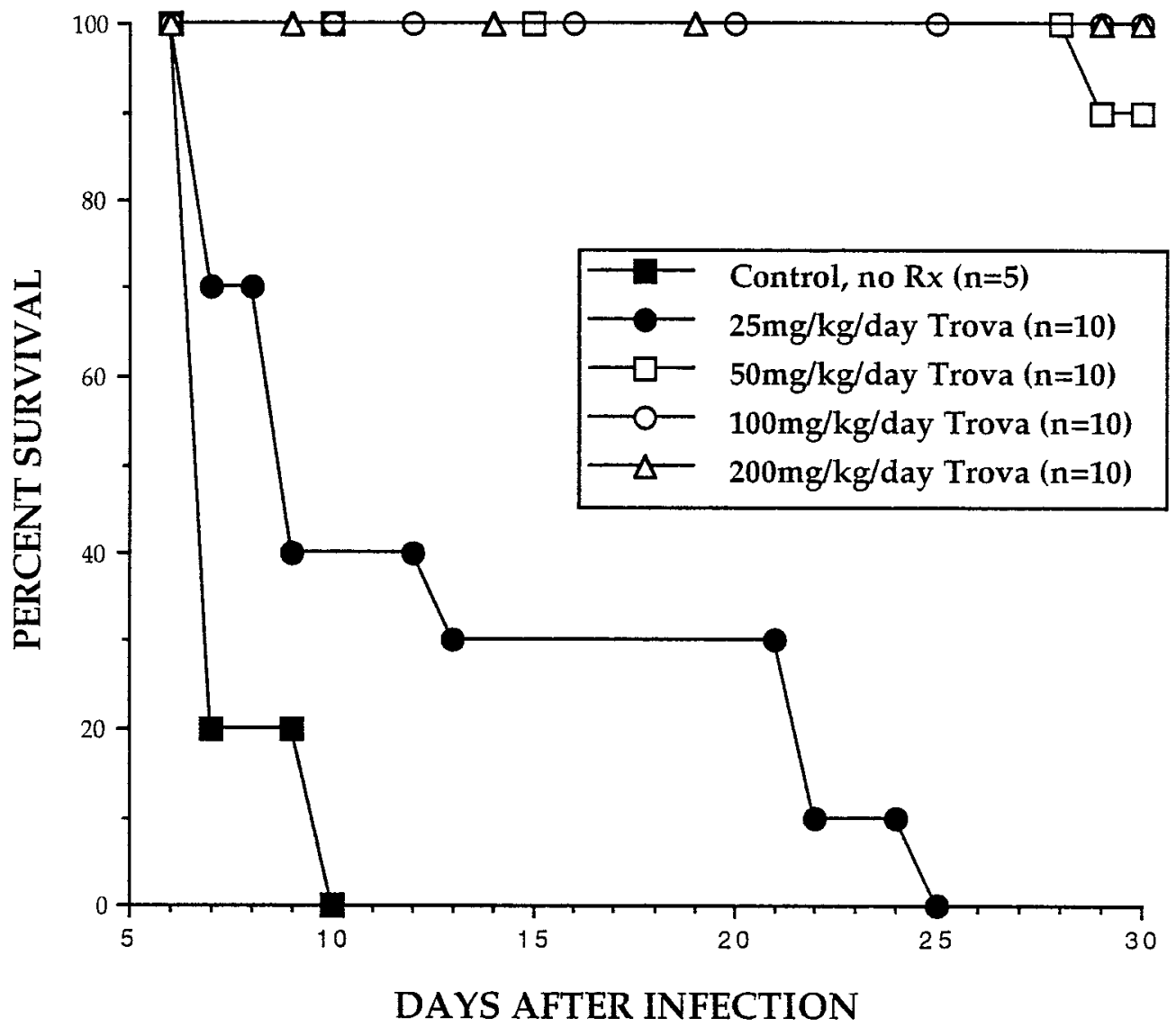

FIG. 3. Effect of treatment with trovafloxacin (Trova) on survival of mice infected intraperitoneally with the RH strain of $T$. gondii. Treatment was by oral gavage. Mice were observed for 30 days from the day of infection. Rx, treatment.

ubility of trovafloxacin at physiological $\mathrm{pH}$ is nonoptimal for intravenous infusions, the prodrug, which rapidly converts to trovafloxacin with a half-life of $4.8 \mathrm{~min}$ in human serum (6), was used. Trovafloxacin concentrations that were active in our in vitro studies were sustained in serum for up to $24 \mathrm{~h}$ and in cerebrospinal fluid for up to $3 \mathrm{~h}$ after the infusion ended (5). Whether trovafloxacin will prove useful in treatment of infections of the central nervous system in infant and adults remains to be studied in appropriately designed studies.

Tosufloxacin also has potent activities against both grampositive and gram-negative bacteria $(12,15,24,25)$ and is structurally similar to trovafloxacin. Trovafloxacin has a 3-azabicyclo[3.1.0]hexane substituent at position C-7 on the naphthyridone nucleus, rather than the common piperazine or 3-aminopyrrolidine substituent in most currently available fluoroquinolones. Of interest is that although tosufloxacin and trovafloxacin differ only in substitution at position C-7 on the naphthyridine ring, tosufloxacin did not have appreciable activity against $T$. gondii either in vitro or in vivo, whereas trovafloxacin was remarkably active. The loss in activity by single substitution in tosufloxacin indicates that derivatization at the C-7 position in the naphthyridine ring is critical for activity against $T$. gondii.

Pharmacokinetic parameters of trovafloxacin in humans, such as a long half-life of elimination, rapid oral absorption, a linear relationship between dose and levels in serum, and achievement of well-tolerated concentrations in serum shown to be active in our in vitro experiments, combined with excel- lent in vitro and in vivo activity against $T$. gondii indicate that trovafloxacin may be useful in treatment of toxoplasmosis in humans.

\section{ACKNOWLEDGMENTS}

This work was supported by grants AI04717 and AI30230 from the National Institutes of Health.

We thank Steven Kim and Ai Nguyen for the excellent technical help.

\section{REFERENCES}

1. Aldridge, K. E., and D. Ashcraft. 1995. Comparison of the in vitro activity of CP 99,219 to that of ciprofloxacin and other antimicrobials against clinical strains of the Bacteroides fragilis group, p. 153, abstr. F232. In Abstracts of the 35th Interscience Conference on Antimicrobial Agents and Chemotherapy. American Society for Microbiology, Washington, D.C.

2. Araujo, F. G., J. Huskinson, and J. S. Remington. 1991. Remarkable in vitro and in vivo activities of the hydroxynaphthoquinone 566C80 against tachyzoites and tissue cysts of Toxoplasma gondii. Antimicrob. Agents Chemother. 35:293-299.

3. Araujo, F. G., J. Huskinson-Mark, W. E. Gutteridge, and J. S. Remington 1992. In vitro and in vivo activities of the hydroxynaphthoquinone $566 \mathrm{C} 80$ against the cyst form of Toxoplasma gondii. Antimicrob. Agents Chemother. 36:326-330.

4. Araujo, F. G., and J. S. Remington. 1974. Effect of clindamycin on acute and chronic toxoplasmosis in mice. Antimicrob. Agents Chemother. 5:647-651.

5. Arguedas-Mohs, A., C. Loaiza, R. Riviera, S. L. Vargas, E. M. S. Goodall, J. S. Bradley, J. Vincent, R. Teng, and J. N. Walterspiel. 1995. CSF penetration of IV trovafloxacin in children. In Program and abstracts of the 1st International Pediatric Infectious Disease Conference. Pediatric Infectious Diseases Society of America and European Society Pediatric Infectious Diseases, Monterey, Calif. 
6. Brighty, K. E., T. D. Gootz, A. Girard, R. Shanker, M. J. Castaldi, D. Girard, S. A. Miller, and J. Faiella. 1995. Prodrugs of CP-99,219 for intravenous administration; synthesis and evaluation resulting in identification of $\mathrm{CP}$ 116,517. In Program and abstracts of the 7th European Congress of Clinical Microbiology and Infectious Disease, Vienna, Austria.

7. Carbone, L. G., B. Bendixen, and G. B. Appel. 1988. Sulfadiazine-associated obstructive nephropathy occurring in a patient with the acquired immunodeficiency syndrome. Am. J. Kidney Dis. 12:72-75.

8. Cohn, J., A. McMeeking, W. Cohen, J. Jacons, and R. S. Holzman. 1989. Evaluation of the policy of empiric treatment of suspected Toxoplasma encephalitis in patients with the acquired immunodeficiency syndrome. Am. J. Med. 86:521-527.

9. Cook, M. K., and L. Jacobs. 1958. In vitro investigation on the action of pyrimethamine against Toxoplasma gondii. J. Parasitol. 44:280-288.

10. Dannemann, B. R., V. A. Morris, F. G. Araujo, and J. S. Remington. 1989. Assessment of human natural killer and lymphokine-activated killer cell cytotoxicity against Toxoplasma gondii trophozoites and cysts. J. Immunol. 143:2684-2691.

11. Derouin, F., C. Sarfati, B. Beauvais, Y. J. F. Garin, and M. Lariviere. 1990. Prevalence of pulmonary toxoplasmosis in HIV-infected patients. J. Acquired Immune Defic. Syndr. 4:1036.

12. Espinoza, A. M., N.-X. Chin, A. Novelli, and H. C. Neu. 1988. Comparative in vitro activity of a new fluorinated 4-quinolone, T-3262 (A-60969). Antimicrob. Agents Chemother. 32:663-670.

13. Eyles, D. E., and M. Coleman. 1953. Synergistic effect of sulfadiazine and Daraprim against experimental toxoplasmosis in the mouse. Antibiot. Chemother. 3:483-490.

14. Eyles, D. E., and N. Coleman. 1955. An evaluation of the curative effects of pyrimethamine and sulfadiazine, alone and in combination, on experimental toxoplasmosis. Antibiot. Chemother. 5:529-539.

15. Fujimaki, K., T. Noumi, I. Saikawa, M. Inoue, and S. Mitsuhashi. 1988. In vitro and in vivo antibacterial activities of T-3262, a new fluoroquinolone. Antimicrob. Agents Chemother. 32:827-833.

16. Goodings, B. B., and R. N. Jones. 1993. In vitro antimicrobial activity of CP-99,219, a novel azabicyclo-naphthyridone. Antimicrob. Agents Chemother. 37:349-353.

17. Hooper, D. C., and J. S. Wolfson. 1991. Fluoroquinolone antimicrobial agents. N. Engl. J. Med. 324:384-394.

18. Israelski, D. M., and J. S. Remington. 1988. Toxoplasmic encephalitis in patients with AIDS. Infect. Dis. Clin. N. Am. 2:429-445.

19. Kenny, G. E., and F. D. Cartwright. 1995. Susceptibilities of Mycoplasma pneumoniae, Mycoplasma hominis, and Ureaplasma urealyticum to a new quinolone: CP-99,219-27, p. 154, abstr. F236. In Abstracts of the 35th Interscience Conference on Antimicrobial Agents and Chemotherapy. American Society for Microbiology, Washington, D.C.

20. Kocagöz, S., D. Gür, S. Ünal, and H. E. Akalin. 1995. In vitro activity of CP-99,219 against clinical isolates, p. 153, abstr. F231. In Abstracts of the 35th Interscience Conference on Antimicrobial Agents and Chemotherapy. American Society for Microbiology, Washington, D.C.

21. Mann, H. J., P. B. Bitterman, A. C. Anderson, R. Teng, A. Johnson, M. Avery, and J. Vincent. 1995. CP-99,219 penetration into human bronchial tissues and fluids following the administration of a single dose, p. 155, abstr. F241. In Abstracts of the 35th Interscience Conference on Antimicrobial Agents and Chemotherapy. American Society for Microbiology, Washington, D.C.

22. Martin, D. H., R. B. Jones, and R. B. Johnson. 1995. A phase II study of CP-99,219-27 (CP) for the treatment of Chlamydia trachomatis $(\mathrm{Ct})$ infections, p. 332, abstr. LM33. In Abstracts of the 35th Interscience Conference on Antimicrobial Agents and Chemotherapy. American Society for Microbiology, Washington, D.C.

23. Maxwell, A. 1992. The molecular basis of quinolone action. J. Antimicrob. Chemother. 30:409-416.

24. Mitsuyama, J.-I., Y. Itoh, M. Takahat, S. Okamoto, and T. Yasuda. 1992. In vitro antibacterial activities of tosufloxacin against and uptake of tosufloxacin by outer membrane mutants of Escherichia coli, Proteus mirabilis, and Salmonella typhimurium. Antimicrob. Agents Chemother. 36:2030-2036.

25. Noumi, T. N. Nishida, S. Minami, Y. Watanabe, and T. Yashuda, 1990. Intracellular activity of tosufloxacin (T-3262) against Salmonella enteritidis and ability to penetrate into tissue culture cells of human origin. Antimicrob. Agents Chemother. 34:949-953.

26. Oksenhendler, E., J. Cadranel, C. Sarfati, C. Katlama, A. Datry, C. Marche, M. Wolf, P. Roux, F. Derouin, and J. P. Clauvel. 1990. Toxoplasma gondii pneumonia in patients with the acquired immunodeficiency syndrome. Am. J. Med. 88:18N-21N.

27. Pomeroy, C., and G. A. Filice. 1992. Pulmonary toxoplasmosis: a review. Clin. Infect. Dis. 14:863-870.

28. Sahai, J., T. Heimberger, K. Collins, L. Kaplowitz, and R. Polk. 1988. Sulfadiazine-induced crystalluria in a patient with the acquired immunodeficiency syndrome: a reminder. Am. J. Med. 84:791-792. (Letter.)

29. Sutcliffe, J. A., T. D. Gootz, and J. F. Barrett. 1989. Biochemical characteristics and physiological significance of major DNA topoisomerases. Antimicrob. Agents Chemother. 33:2027-2033.

30. Teng, R., L. C. Dogolo, S. A. Willavize, and J. Vincent. 1995. Effect of age and gender on the pharmacokinetics of CP-99,219, a new quinolone antibiotic, in healthy volunteers, p. 154, abstr. F238. In Abstracts of the 35th Interscience Conference on Antimicrobial Agents and Chemotherapy. American Society for Microbiology, Washington, D.C.

31. Teng, R., S. C. Harris, D. E. Nix, J. J. Schentag, G. Foulds, and T. E. Liston. 1995. Pharmacokinetics and safety of trovafloxacin (CP-99,219), a new quinolone antibiotic, following administration of single oral doses to healthy male volunteers. J. Antimicrob. Chemother. 36:385-394.

32. Torroba, A. L., D. J. Hermida, B. C. Ezpeleta, and Z. E. Munoz. 1988. Metahemoglobinemia secundaria al tratamiento de infecciones oportunistas en pacientes con SIDA. Rev. Clin. Esp. 182:289-290. (Letter.)

33. Van Der Pol, B., and R. B. Jones. 1995. In vitro activity of CP99,219 agains Chlamydia trachomatis, p. 154, abstr. F237. In Abstracts of the 35th Interscience Conference on Antimicrobial Agents and Chemotherapy. American Society for Microbiology, Washington, D.C.

34. Visalli, M., M. Jacobs, and P. Appelbaum. 1995. Antipneumococcal activity of CP 99,219, ciprofloxacin, lomefloxacin, clinafloxacin, sparfloxacin an cefuroxime by time-kill testing, p. 154, abstr. F233. In Abstracts of the 35th Interscience Conference on Antimicrobial Agents and Chemotherapy. American Society for Microbiology, Washington, D.C.

35. Wise, R., D. Mortiboy, J. Child, and J. M. Andrews. 1996. Pharmacokinetics and penetration into inflammatory fluid of trovafloxacin (CP-99,219). Antimicrob. Agents Chemother. 40:47-49.

36. Wong, S.-Y., D. M. Israelski, and J. S. Remington. 1994 AIDS associated toxoplasmosis, p. 460-493. In M. A. Sande and P. Volberding (ed.), The medical management of AIDS, 4th ed. The W. B. Saunders Co., Philadelphia.

37. Wong, S.-Y., and J. S. Remington. 1994. Toxoplasmosis in the setting of AIDS, p. 223-257. In S. Broder, T. C. Merigan, and D. Bolognesi (ed.), Textbook of AIDS medicine. The Williams \& Wilkins Co., Baltimore.

38. Zimmer, C., K. Storl, and J. Storl. 1990. Microbial DNA topoisomerases and their inhibition by antibiotics. J. Basic Microbiol. 30:209-224. 